\title{
UKRAINIAN PRICE CONTROL POLICY
}

In October 2016 Ukraine stopped permanent price control policy for essential goods. Instead, the government has started a temporary 90 days policy for basic goods. It means that any time authority can provide any types of price control policy no longer than 90 days per year. "Any time" is when the economy and society will need government interaction to market pricing in order to control prices. "Any types" of policy means that authority can implement fixed (frozen) prices which is the strictest type of the policy as well as control of producers' declarations for pricing, which is the least controlled type of the policy. As that the new policy has been just started, there is no much possibility to analyse its consequences. However, this study proposes to analyse permanent price control policy, which has been implemented till 2016 in Ukraine. Because of the absence of the possibility to analyse the new policy, our strategy is based on two points: the first one is to understand needless of price control policy and the second one is to verify the efficiency of provided permanent PCP. It will give understanding whether there were reasons against permanent price control policy as well as the experience of implementing temporal price control policy. In order to understand the needless of permanent price control policy, we proposed to understand the stage of transition of the Ukrainian economy. Based on the difference in abilities of price to reflect quality in the market and planned economies, we used it as a tool for covering research question. Moreover, the quality of the product was decomposed into intrinsic and extrinsic attributes, what allows providing more analysis that is accurate. Therefore, based on the results from the hedonic regression, Ukrainian consumption market is characterized by significantly positive intrinsic price effect and significant brand awareness price effect. Literature evidence suggests that such price abilities are inherent to free markets. Only significant country of origin price effect displays features of the planned economy. The conclusion is that the Ukrainian economy is on its last stages of transition to market economy. Therefore, consumer market is able to reallocate resources efficiently and satisfies the need of all consumers. As result, in the current stage of transition of the Ukrainian economy, there is no need in permanent price control policy. Obtained results demonstrated that the last price control policy was inefficient. Using hedonic pricing regression, we showed that the product from pricecontrolled market has greater prices than its alternative from the free market. Therefore, it underlines the negative overlooked effect from provided PCP.

Keywords: price control policy (PCP), efficient and inefficient PCP, transition market, market of essential goods, temporary and permanent PCP.

Introduction. The main idea of price control policy is to make essential products affordable for poor people (Alexeev and Leitz, 2001). In turn, a product from the essential market has to cost less than its substitute from the free market (we propose to call such policy "efficient"). Therefore, one of the reasons to stop permanent PCP (price control policy) is the inefficiency of provided policy. In order to check it we are going to compare prices of products from a free market with prices from price-controlled market using hedonic regression.

The experience of implementing temporal price control policy might be when there is no more need in permanent PCP. Since 1991 Ukraine has become independent and started its way to free market economy. Since that time till now, its economy is still in transition. Transition or emerging economy adopts features of both, planned and market economies. On the one hand, rapid process of liberalization as the way to free economy, on another hand, a great share of the poor population still needs government support and price controls as the echo from command economy (Alexeev and Leitzel, 2001). However, the closer economy to the market type, this echo is weaker. Alternatively, if the Ukrainian economy is convenient to 
free, there is no need in permanent price control policy.

In order to check the stage of Ukrainian transition, in turn, the need in permanent price control policy, we propose the methodology which is based on the ability of price to reflect quality. Under different market conditions, this strength is different. The closer economy to a free market, the ability of price to reflect quality is greater.

In order to verify how quality (immeasurable parameter) affects price, we are going to split quality into its consistent characteristics: intrinsic and extrinsic cues (measurable parameters). Intrinsic quality attributes are inherent to the product itself and are strongly identified with its physical and chemical composition (e.g. taste, aftertaste, etc), while extrinsic attributes are non-sensory characteristics surrounding the product (e.g. package, brand name, region of production, etc.) (Dodds, Monroe \& Grewal, 1991; Olson, 1977; Lichtenstein, Ridgway \& Netemeyer, 1993; Olson and Jacoby, 1972). As a proxy for intrinsic attributes, we are going to use the results from blind taste preference tests, where consumers and professionals blindly try commodity and make their choice from the set of alternatives, generating ratings. In the case of food product (search good), which is characterized by easily revealed sensory components (Jourdan, 2001), we expect these variables to display true intrinsic quality. Eventually, with respect to Nelson (1970), ratings can be used as proxies for quality. In Ukraine, blind taste test experiments were the base of the social TV show, "Quality Mark", which had been run since 2005. The dataset has a wider variety of commodities including meat and milk products, frozen food, fish products, bakery and sweets, can food, fruits and vegetables, alcohol, other drinks, spices and additions, groats and pasta, snacks. In addition to food products, there are beauty care commodities, clothes and other home stuff (see Appendix A). Therefore, the dataset consists of essential as well as normal products.

Moreover, as proxies for extrinsic quality, we chose brand name and country of origin among the wide set of surrounding attributes of the product, since these indicators are believed to have the greatest effect on price according to the existing literature.

Additionally, we are going to deal with frequency of usage as a control variable for consumers' objective knowledge about the 'exact' quality of the product (experienced or search well) and type of the product (essential or not) in order to distinguish between price controlled and price uncontrolled goods markets. The sources of data are consumption basket and a list of essential goods certified by the Ministry of Economy from Ukraine.

Using a hedonic pricing procedure, what allows to determine the share of every attribute in price, we are going to analyze intrinsic and extrinsic price effects for commodities from consumption market in Ukraine. Therefore, hedonic pricing will display the ability of price to reflect quality.

The results of this paper might be used as the analysis of the permanent price control policy, which has been provided until October 2016 in Ukraine. Therefore, the outcomes might be applicable for policymakers as a support (or refutation) of the letting prices of essential products to be free (at least 270 days per year) and providing efficient price control policy during the required time (at most 90 days per year).

Literature evidence.

Evidence for the expedience of temporal PCP.

A. By the law.

A.1 Arguments.

Providing the evidence of needlessness in permanent PCP in Ukraine, there are few arguments for the expedience of temporal PCP.

The first argument comes from the analyze of the changes in the list of essential products and severity of the types of price control policies for the whole transition period till October (the evolution of the list of essential products and changes in types of the PCP is summarized and displayed in the table form, which can be found in Appendix C), 2016. With time, the Ukrainian government decreases their interaction to the economy, 
in turn, price controls have been becoming less and less strict. In terms of prices and their ability to reflect quality it means that, a decrease in government interaction allows the market to distribute resources more efficiently, in turn, prices convey more information about quality. Concluding, the Ukrainian economy in transition moves towards a market economy by providing less strict price control policies.

The second argument is based on the specificity of policies implemented by the Ukrainian government. Historically, Ukrainian authority tries to avoid its impact on a quality of the product providing price control policy. This fact shows the intention of the government to make essential products compatible in quality with their alternatives from the free market, in turn, they tried to make these markets similar what leads to easier merging process in future.

A.2 Analyze of law.

1. Law of Ukraine on prices and pricing;

2. Resolution on changes the regulation of prices and tariffs.

From 1991, the starting point of country transition, to 1996, government-controlled prices by setting limited value-adds. There were controlled around $75 \%$ of the market. Till October 2016 , the limit was 10 $15 \%$ depending on the type of the product. This method does not have any impact on the manufacturer, because limited value adds are implemented only to distributors. Therefore, there is no impact on input costs, in turn, the quality of products should not be affected by price control policy.

Starting from 1996, additionally, to limited value-adds, there have been introduced standard norms of profitability for some essential goods (powder, bread and baking products). Till October 2016, it was around $10 \%$. According to such price control schema, the quality of inputs should not be decreased, therefore, the product quality supposed to be at least as good as without control policy. In 1999, the list of essential consumption products consists of around 17 types of commodities: 14 products controlled by value adds a policy, 3 are under profit control policy.

In 2007 the greatest part of the prices of basic goods started to be controlled according to their declaration. Therefore, in case if the producer has the intention to change the price or to provide a new product with a new price, it should be agreed with the government first. In the declaration, producer argues the reasons of price increase or price setting and controlling institute (as usual it is a local authority) makes a decision about allowing to appear product with its price at the market. This method allows the producer to make prices by itself, the only condition is that it has to be justified. Therefore, it is the most democratic schema of price control policy. Since 2007 till October 2016 there are $80 \%$ of essential (eatable) products which are controlled according to declaration schema (12 out of 15).

Eventually, the history of the types of price control policy had 3 stages (Figure 1): limited value adds (average level of strictness, no impact on quality), after there were introduced standard norms of profitability only for 3 types of products (stricter, no impact on quality), and the latest type is control by declaration (the least strict, no impact on quality). Therefore, in the last periods of permanent PCP, policy had the most sparing character. Alternatively, there were small level of government interaction into pricing. Moreover, such policy has been run for around 10 years and it has ended up in temporal price control policy as its logical continue.

\section{B. By the analyze of the stage of Ukrainian transition.}

Despite the evidence from the trend in structure and mechanism design of PCP, there is the second way of demonstrating the needless in permanent price control policy. There is no need in the controlled policy if Ukrainian consumption market has features of the free market, alternatively, it distributes resources efficiently and satisfies needs of all consumers with different budgets.

In order to verify the stage of transition of the Ukrainian economy, one way is to establish the level of price ability to reflect quality. This proposition is based on the difference in a price-quality relationship under different market conditions: planned and market economies. 


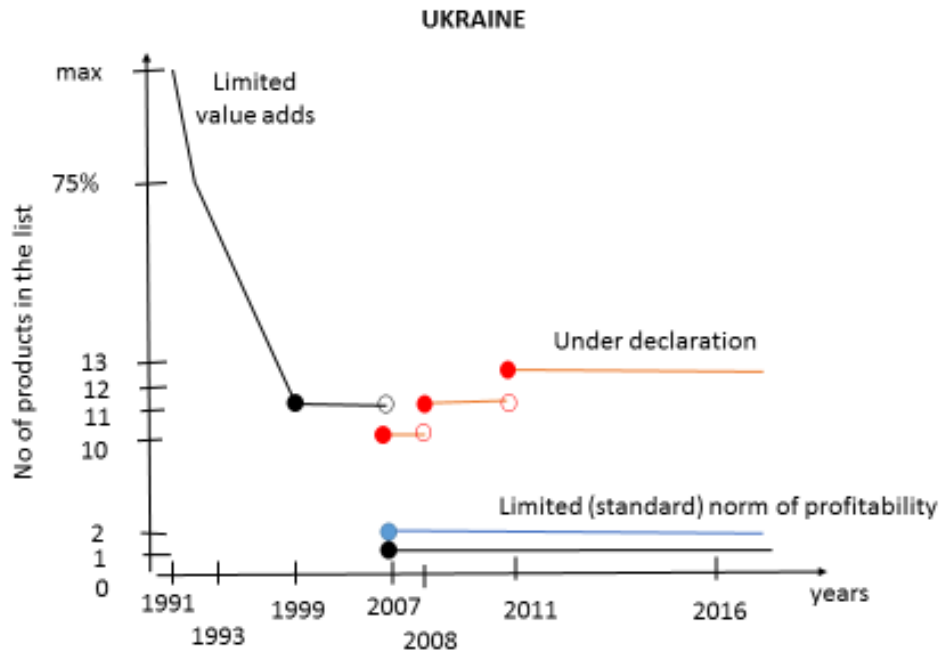

Figure 1 - Trend of essential goods

B.1 Price-quality relationship under market extremes. The closer a country to the market economy, the level of price control decreases. In a free economy, where resources are distributed between private ownership according to the market law, prices serve as "invisible hand" (Smith, 1904), guiding production to the best interest of society. Therefore, the information conveyed by market prices reflect the quality of inputs that producer used (Mises, 1981; Hayek, 1945; Fama, 1970; Grossman and Stiglitz 1976 and others), in turn, it displays the product quality. Eventually, in a free economy, prices serve as a signal of quality (Farrell 1980; Gabor and Granger 1966; Leavitt 1954; Scitovsky 1944; Spence 1974). The higher the price, quality believed to be higher (Leavitt, 1954; Tull, Boring, and Gonsior, 1964; Gabor and Granger, 1966; and McConnell, 1968).

In a planned or centralized economy, consumption and production decisions are made not with an aim of utility and profit maximizations, but by the government (Mises, 1981). Under the best intention of central planners, they lack the information, which Hayek (1945) called "the knowledge of the particular circumstances of time and place". This is the sort of information, which can be obtained only from a particular buyer or seller at a specialized industry or location. Alternatively, this is a knowledge about the individual specificity of consumers and producers about their tastes and preferences at the exact point on time. Therefore, because of the lack of this part of the information, the authority cannot longer provide prices which convey the whole set of cues.

Therefore, the evidence demonstrates the difference in the price-quality relationship between two extremes: planned and market economy. In turn, the closer economy to one of the extremes, price-quality relationship absorbs the greater share of features of that extreme.

In order to verify the ability of price to reflect quality, we propose to decompose quality attributes according to their nature into intrinsic and extrinsic characteristics (Jourdan, 2001). Based on definitions, intrinsic quality attributes and extrinsic quality attributes might have a different impact on prices in case of free market comparing with the price-controlled market.

B.2 Intrinsic price effect under different market conditions. Based on Lowengard and Cohen (2006) findings, there is a positive significant dependence between aroma, taste, aftertaste, etc. and price of the wine. Moreover, Oczkowski and Doucouliagos (2014) estimated more than forty studies about hedonic 
pricing for the wine market with certain characteristics and proved the positive correlation between sensory quality and prices. Therefore, there is a positive significant intrinsic price effect.

There is no direct evidence about the type of the market where the experiment was run. However, based on the fact, that the object of research is wine, which is not inherent to essential goods, we might conclude that the results were driven for the free market. In turn, we might expect that there is a positive significant intrinsic price effect in the free market.

Unfortunately, there are no studies discussing intrinsic price effect in the planned economy. However, based on Hayek (1945) and his statement about the lack of "the knowledge of the particular circumstances of time and place" described earlier, we can conclude, that during pricing process, the government fails to catch taste preferences of consumers, therefore, prices at the controlled market cannot reflect intrinsic quality.

B.3 Extrinsic price effect under different market conditions. As it was stated before, extrinsic quality consists of surrounding items of product. In this research, we are discussing country of origin and brand awareness, which are believed to have the greatest effect on price.

Brand awareness. According to Kotler and Keller (2006), a brand is defined as a name, term, sign, symbol or design or a combination of these intended to identify the goods or services of one seller or group of sellers and to differentiate them from those of competitors. The brand is considered as a signal of product quality (e.g. Dodds et al., 1991). According to Shwu-Ing and Li-Pang (2014), there is positive brand awareness impact on price. However, unlike our research, they based their results on IT markets (free market). To my knowledge, there is no direct evidence linking the brand name and its effect on the price of consumer products.

Speaking about a planned economy, consumers were buying what was available on the market without the wide choice of it. As usually, within one product category there was only one brand produced by the government (Neelankavil and Rai, 2009). Moreover, state organizations are non-profit. According to Stride and Lee (2007), brand awareness price effect for non-profit organizations is insignificant.

Therefore, there is no strong evidence about the significance of brand awareness price effect no at free market neither in the planned economy.

Country of origin. In a row with the brand name, an additional informational cue which provides consumers with a base for evaluating the product is a country of origin or "made in" concept. Bilkey and Nes (1982) provide the literature review that highlights strong evidence for a country of origin effects on consumption decision, what gives the evidence to expect a significant country of origin price effect.

The difference between domestic and foreign prices in the planned economy was discussed by Thomas A.Wolf in his book "Foreign Trade in the Centrally Planned Economy". He stated that because of the set of factors, among which is the protection of domestic goods, the price for imported products is higher than domestic. Therefore, there is a significant country of origin price effect in the centralized economy.

Discussing country of origin price effect at the market economy, based on Massow (1989), in free economy prices of domestic goods are close to the world market, therefore, there is no big difference between prices of imported and domestic commodities. Alternatively, there is no significant country of origin price effect in the free market.

Having discussed evidence of brand awareness price effect and country of origin price effect, it is possible to conclude that the closed economy to the market economy, the less significant of extrinsic price effect is. This conclusion is based on the country of origin price effect only, because of the insignificance of brand awareness price effect under both extremes.

Therefore, there is no need in permanent PCP if the features of free economy dominate in a transition economy. Based on the evidence, the needlessness in PCP would be proved, if there is a significant impact of intrinsic quality on price, insignificant country of origin price effect and significant brand 
awareness price effect.

Evidence for the uselessness of PCP in case of inefficient policy. One of the negative overlooked effects of price control policy is that in long run prices for controlled goods are greater than free prices. This effect was described by Christopher and Rachel Coyne (2015), Fiona Morton (2001) and many other authors who dealt with the problems of price controls.

The simplest explanation for it is that, unlike producers of controlled goods, suppliers of uncontrolled (free price) commodities are profit motivated and they are investing in developing their products. In turn, the production becomes less costly with time, as result, the price goes down. Therefore, prices on the free market become less then prices on the controlled market Authors suggest that such situation is an evidence that there is little political pressure to reverse the controls and price control policy becomes disconnected in the minds of policymakers from the original aim of the policy (Christopher and Rachel Coyne, 2015). Alternatively, such price control policy is not efficient any more.

Therefore, when the policy does not reach its aim and authority does not care much about it, there is no sense in such a policy.

Econometric model. In order to test the experience of providing temporal price control policy, the hedonic regression is applied. Referring to Long et al. (2007), according to Lancaster (1966) and Rosen (1974), the hedonic analysis is a method for decomposing a commodity into its consistent characteristics and estimating their implicit prices. Therefore, in order to find price-quality dependence, we would divide quality into extrinsic and intrinsic attributes.

That is, transforming price into its logarithm in order to get rid of possible non-linearity issue, the function is:

$$
\text { lnPrice }=\text { fn (Quality parameters, Non quality parameters) }
$$

where Quality parameters consists of intrinsic cues, presented by consumers' ratings and professionals' rating and extrinsic attributes, presented by country of origin and brand awareness. Non quality parameters are presented in order to control for more influencing factors and displayed by frequency of purchasing and price control policy.

Refethe rring to Long at el. (2007) and Bao and Wan (2007) the most traditional way for hedonic (implicit) pricing estimation is Ordinary Least Squares (OLS) regression. Therefore, the basic regression equation appears as follows:

$$
\begin{aligned}
& \operatorname{lnP}_{i j}=\alpha+\sum_{k=2}^{K} \beta_{1 k} I\left(\text { CChoice }_{i j}=k\right)++\sum_{s=2}^{S} \beta_{2 s} I_{\left(\text {PChoice }_{i j}=s\right)+\gamma_{1} \text { Domestic }_{i j}+\gamma_{2} \text { GoogleTrend }_{i j}+} \\
& \left.+\sum_{s=2}^{S} \beta_{2 s} I\left(\text { PChoice }_{i j}=s\right)+\gamma_{1} \text { Domestic }_{i j}+\gamma_{2} \text { GoogleTrend }_{i j}+\sum_{l=2}^{L} \delta_{1 l} \text { IfrUsage }_{i}=l\right)+\delta_{2} \text { Controlled }_{i}+ \\
& +\sum_{t=2}^{T} \mu_{t} I\left(\text { Pear }_{i j}=t\right)+\sum_{c=2}^{C} \partial_{c} \text { C }\left(\text { Category }_{i}=c\right)+u_{i j}
\end{aligned}
$$

where $P_{i j}$ denotes price for good $i$ from producer $j$, ordinal variables CChoice $_{i j}$ and $P$ Choice ${ }_{i j}$ (Dummy variables, stand for 0 if the ratings are 1 (worse) or 2 (bad), and 1 if the ratings are 3 (good), 4 (better) or 5 (the best)) are ratings for $j$ subtype of good $i$ made by consumers and professionals respectively. Here GoogleTrend G $_{i j}$ reflects the level of recognition of the brand. It is presented by the average search volume index from January 2012 till January 2016. Google trend for product $i$ from $j$ producer is calculated as follows:

$$
\text { GoogleTrend }_{i j}=\frac{\text { Number of quieres of brand name }}{i j}
$$


Country of origin is presented by Domestic $c_{i j}$, which is dummy variable equal $s$ to 1 if the good was

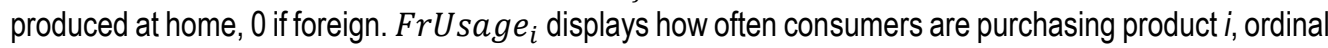
variable ( 1 is once per a year and 2 is once per half a year (constitute the group of Low frequency of usage), 3 is once per quarter and 4 is monthly (compile the group of Medium frequency of usage), 5 is weekly and 6 is daily (compile the group of High frequency of usage). Controlled is a dummy variable, which displays the market with respect to price control policy implementation. It equals to 1 if the good belongs to essential commodity (comes from price controlled market) and 0 if the good is non essential and comes from free market, i.e., price is non controlled. This variable the the serves as the base the for decomposing set of observations for two groups: products fa a rom price controlled market and products from free market.

Here Year $_{i j}$ stands to capture price differences caused by inflation or other exogenous shocks. It is dummy variable, created for each year. Cate gor $y_{i}$ presents category of the product, e.g. a milk product, meat product, bakery, canned product, etc.

$K$ and $S$ are numbers of ratings of consumers and professionals respectively. $L$ displays the number of orders in the frequency of purchasing. $T$ is a number of years when prices were collected. $C$ is a number of categories of the products.

Therefore $\beta_{1}, \beta_{2}$ and $\gamma_{1}, \gamma_{2}$ are coefficients, which determine the level of impact of intrinsic and extrinsic quality characteristics on price. Based on the literature evidence, the needless of permanent PCP will be proved, if these coefficients convey features of free market, e.g. $\beta_{1}$ and $\beta_{2}$ are significantly positive coefficients (significantly positive intrinsic price effect) (Lowengard and Cohen, 2006; Oczkowski and Doucouliagos, 2014), $\gamma_{1}$ coefficient, which represents country of the price effect, is insignificant (Massow, 1989) and there is uncertainty about $\gamma_{2}$ coefficient, which represents brand awareness price effect.

$\delta_{2}$ represents the difference in prices between price controlled market and free market. Therefore, based on this coefficient it would be possible to conclude about efficiency of price control policy in Ukraine.

There are I commodities with $J$ products from different producers for each commodity. Therefore, the number of observations is equal to $\sum_{i=1}^{I} \sum_{j=1}^{J} x_{i j}$ for each country.

Data. Data collecting. Ukrainian dataset was collected in several stages. As a first step, a base with results of the blind preference taste test experiment was obtain from "Quality mark" Ukrainian TV show (Archive of the TV show "Quality mark" is available at http://inter.ua/ru/video/program/zk). During one examination there is one type of commodity from five different producers. Therefore, the dataset consists of 340 experiments which are 1675 commodities. Approximately 50 consumers and 5 professionals were tasting goods in each attempt. Every participant gave his vote for one of the best product among alternatives. As a result, each set of commodities was assigned a rank based on participants' votes. Therefore, consumers' choice rating and professionals' choice rating parameters are ordinal variables and take values from one to five, where one is the worst and five is the best evaluation. Distribution of votes within each grade is almost equal in the data.

The second stage, where extrinsic attributes and non-quality parameters were collected. Therefore, a region of production is stated to be equal one for domestic products and zero otherwise. As result, around $80 \%$ of tested products are produced in the home country, while $20 \%$ of commodities were imported.

The search volume index which serves as a proxy for brand credibility was defined as the average of normalized quires of the brand name starting from January 2012 till 2016. In order to get this index, brand names from different producers of the same commodity were compared in Google Trend searching system.

The frequency of usage adopts a form of categorical variable and takes value from 1 (once per year) to 6 (everyday purchasing). The Regulation of Ministry of Economics and Development of Ukraine "Approval of the set of food products, non-food products and set of services" was used as a source of 
data. The higher shares of goods are purchased weekly and monthly (37\% and $35 \%$ respectively).

Type of the good was defined from the list of socially imported goods (services) the prices for which are controlled by the Ministry of Economics and Development of Ukraine. Therefore, dataset consists of around $80 \%$ of non-essential or price uncontrolled goods and $20 \%$ of essential goods, i.e. price controlled commodities. In other words, the prices for $20 \%$ of commodities are controlled by the government.

And finally, information about prices as the dependent variable was collected from the field. Each commodity is presented by one price calculated as an average of prices collected from five different shops (supermarkets). There is a timing issue because the prices were accumulated in different years, starting from 2005. Therefore, to make price comparable, dummies for the year will be used. Moreover, all prices were defined for one standard size (100 gr).

As the result, including all data gathering issues, there are 428 observations.

Data description. Data was collected from Ukrainian social TV show over periods 2002 till 2012.

Dataset is presented by wide variety of commodities, categorized as milk and meat products, fish products, mushrooms, frozen foods, alcohol, soft drinks (including tea and coffee), bakery and sweets, groats and pastas, canned vegetables and canned fast food, fruits and vegetables, spices and other additions, snacks. The set includes non eatable commodities: clothes, beauty and care, home stuff and others ( $10 \%$ of all dataset). More detailed list of commodities can be found in Appendix A.

Each product is characterized by consumers' evaluation and professionals' evaluation as proxies for intrinsic quality. Based on consumers' and experts' votes, the product with rating 1 is the worst and 5 is the best. Therefore, based on categories, the distribution of consumers' ratings and professionals' rating is presented in Table 1. Categories of products, presented in the table, are ordered from the most to the least required products according to consumption basket (http://agravery.com/uk/posts/show/nerealnijminimalizm-ci-mozna-viziti-z-minimalnim-spozivcim-kosikom-na-prozitkovij-minimum)

Table 1 - Data description. Intrinsic quality. Ukrainian products and their consumers' and professionals' evaluations

\begin{tabular}{|c|c|c|c|c|c|c|}
\hline \multirow{3}{*}{ Category } & \multicolumn{6}{|c|}{ UKRAINE } \\
\hline & \multirow{2}{*}{$\begin{array}{c}\text { Num of } \\
\text { observations }\end{array}$} & \multicolumn{2}{|c|}{ CChoice ratings } & \multicolumn{2}{|c|}{ PChoice ratings } & \multirow{2}{*}{ Diff of means } \\
\hline & & Min-max & Mean & Min-max & Mean & \\
\hline 1 & 2 & 3 & 4 & 5 & 6 & 7 \\
\hline Milk products & 195 & $1-5$ & $\begin{array}{c}3.13 \\
(0.095)\end{array}$ & $1-5$ & $\begin{array}{c}3.23 \\
(0.06) \\
\end{array}$ & $\begin{array}{l}-0.09 \\
(0.1) \\
\end{array}$ \\
\hline $\begin{array}{c}\text { Groats and } \\
\text { pastas }\end{array}$ & 65 & $1-5$ & $\begin{array}{l}3.08 \\
(0.1) \\
\end{array}$ & $2-5$ & $\begin{array}{c}3.94 \\
(0.09) \\
\end{array}$ & $\begin{array}{c}-0.86^{\star \star \star} \\
(0.2) \\
\end{array}$ \\
\hline $\begin{array}{c}\text { Fruits and } \\
\text { vegetables }\end{array}$ & 130 & $1-5$ & $\begin{array}{c}2.91 \\
(0.12)\end{array}$ & $1-5$ & $\begin{array}{c}3.25 \\
(0.07)\end{array}$ & $\begin{array}{c}-0.35^{\star \star *} \\
(0.12)\end{array}$ \\
\hline Meat products & 269 & $1-5$ & $\begin{array}{c}2.99 \\
(0.09) \\
\end{array}$ & $1-5$ & $\begin{array}{c}3.12 \\
(0.05) \\
\end{array}$ & $\begin{array}{l}-0.12^{*} \\
(0.09)\end{array}$ \\
\hline $\begin{array}{c}\text { Bakery and } \\
\text { sweets }\end{array}$ & 160 & $1-5$ & $\begin{array}{l}3.17 \\
(0.1) \\
\end{array}$ & $1-5$ & $\begin{array}{c}3.25 \\
(0.08) \\
\end{array}$ & $\begin{array}{l}-0.08 \\
(0.13)\end{array}$ \\
\hline Fish products & 185 & $1-5$ & $\begin{array}{l}3.02 \\
(0.1) \\
\end{array}$ & $1-5$ & $\begin{array}{c}2.98 \\
(0.07) \\
\end{array}$ & $\begin{array}{c}0.04 \\
(0.11)\end{array}$ \\
\hline $\begin{array}{l}\text { Canned } \\
\text { products }\end{array}$ & 85 & $1-5$ & $\begin{array}{c}3.21 \\
(0.14)\end{array}$ & $1-5$ & $\begin{array}{c}3.33 \\
(0.09)\end{array}$ & $\begin{array}{l}-0.12 \\
(0.15)\end{array}$ \\
\hline Mushrooms & 20 & $1-5$ & $\begin{array}{c}3.2 \\
(0.31)\end{array}$ & $1-4$ & $\begin{array}{c}3.05 \\
(0.18) \\
\end{array}$ & $\begin{array}{l}0.15 \\
(0.4) \\
\end{array}$ \\
\hline Frozen products & 80 & $1-5$ & $\begin{array}{c}2.93 \\
(0.15)\end{array}$ & $1-5$ & $\begin{array}{c}3.23 \\
(0.09)\end{array}$ & $\begin{array}{l}-0.3^{* *} \\
(0.17)\end{array}$ \\
\hline
\end{tabular}


table 1

\begin{tabular}{|c|c|c|c|c|c|c|}
\hline 1 & 2 & 3 & 4 & 5 & 6 & 7 \\
\hline Alcohol & 20 & $1-5$ & $\begin{array}{c}3.7 \\
(0.24)\end{array}$ & $2-4$ & $\begin{array}{c}3.55 \\
(0.15)\end{array}$ & $\begin{array}{c}0.15 \\
(0.26)\end{array}$ \\
\hline $\begin{array}{c}\text { Nonalcoholic } \\
\text { drinks }\end{array}$ & 129 & $1-5$ & $\begin{array}{c}3.1 \\
(0.11)\end{array}$ & $1-5$ & $\begin{array}{c}3.59 \\
(0.07)\end{array}$ & $\begin{array}{c}-0.49^{* * *} \\
(0.13)\end{array}$ \\
\hline $\begin{array}{c}\text { Spices and } \\
\text { additions }\end{array}$ & 75 & $1-5$ & $\begin{array}{c}3.01 \\
(0.17)\end{array}$ & $1-5$ & $\begin{array}{c}3.55 \\
(0.12)\end{array}$ & $\begin{array}{c}-0.53^{* * *} \\
(0.21)\end{array}$ \\
\hline Snacks & 20 & $1-5$ & $\begin{array}{c}2.75 \\
(0.32)\end{array}$ & $1-5$ & $\begin{array}{c}3.05 \\
(0.18)\end{array}$ & $\begin{array}{c}-0.3 \\
(0.24)\end{array}$ \\
\hline \hline Clothes & 20 & $1-5$ & $\begin{array}{c}3.05 \\
(0.36)\end{array}$ & $1-5$ & $\begin{array}{c}3.5 \\
(0.28)\end{array}$ & $\begin{array}{c}-0.45^{*} \\
(0.33)\end{array}$ \\
\hline Beauty and care & 30 & $1-5$ & $\begin{array}{c}2.77 \\
(0.28)\end{array}$ & $1-5$ & $\begin{array}{c}3.23 \\
(0.23)\end{array}$ & $\begin{array}{c}-0.47^{*} \\
(0.33)\end{array}$ \\
\hline Home products & 100 & $1-5$ & $\begin{array}{c}3.01 \\
(0.15)\end{array}$ & $1-5$ & $\begin{array}{c}3.58 \\
(0.11)\end{array}$ & $\begin{array}{c}-0.57^{* * *} \\
(0.18)\end{array}$ \\
\hline Other & 85 & $1-5$ & $\begin{array}{c}2.95 \\
(0.17)\end{array}$ & $1-5$ & $\begin{array}{c}3.21 \\
(0.11)\end{array}$ & $\begin{array}{c}-0.26^{*} \\
(0.19)\end{array}$ \\
\hline \hline TOTAL & 1668 & $1-5$ & 3.05 & $1-5$ & 3.29 & $\begin{array}{c}-0.24^{\star * *} \\
(0.04)\end{array}$ \\
\hline
\end{tabular}

Note: Standard errors in parentheses ${ }^{*} p<0.1,{ }^{* *} p<0.05,{ }^{* * *} p<0.01$

Where $p$ is probability that difference of means is zero

Results from Table1 show that consumers and experts differently evaluate the products. Rao and Monroe (1988) explained this fact based on the difference in evaluative schema between consumers and professionals. From Table 1 , it is observable that professionals estimate the intrinsic quality of the product in a more optimistic way comparing with consumers. The reason of it can be in the different level of knowledge and familiarity with the true quality of the product and non-persistent in taste preferences (Garbarino and Strahilevits, 2004). Comparing consumers' and professionals' ratings, professionals' evaluations are higher comparing with consumers'.

The most popular categories in Ukrainian TV show are milk and meat products, fish and non-alcoholic drinks, bakery and sweets and fruits and vegetables. According to consumers' ratings, the highest quality category is canned food. Professionals gave better evaluations for groats and pasta. The significant difference between professionals' and consumers' ratings were found for meat, frozen food, nonalcoholic drinks, groats and pasta, fruits and vegetables, spices and additions and for all non eatable goods.

Despite intrinsic characteristics, each product is characterized by country of origin and Google search index. Table 2 presents their distribution among categories with respect to the information about the level of price control.

Analyzing the price controlled and price uncontrolled markets, the biggest share of milk and meat products belong to price-controlled market. It means that these categories were heavily controlled by the Ukrainian government. Moreover, most of meat and milk commodities are mostly from domestic producers. Price controls along with the preponderance of domestic production are the result of food security (Byerlee et.al., 2006). Moreover, as table shows, a greater number of eatable products was produced in Ukraine, unlike clothes, beauty and care, home stuff and others, the higher shares of which have been imported from foreign countries. Based on Pourroy (2016), the greater share of domestic products is typical for transition economy. Therefore, according to extrinsic cues, the food market is still in transition, however, a market with uneatable products is in a free market. 
Table 2 - Distribution of price controlled and price uncontrolled goods as well as their extrinsic characteristics by categories

\begin{tabular}{|l|c|c|c|c|c|c|}
\hline \multirow{2}{*}{ Categories } & \multicolumn{9}{|c|}{ UKRAINE } \\
\cline { 2 - 7 } & \multirow{2}{*}{ Controlled } & \multirow{2}{*}{ Free } & \multirow{2}{*}{ Domestic } & \multirow{2}{*}{ Foreign } & \multicolumn{2}{c|}{ Search Index } \\
\cline { 3 - 7 } & & & & & Low & High \\
\hline \hline Milk products & 120 & 65 & 164 & 21 & 66 & 72 \\
\hline Groats and pastas & 35 & 25 & 48 & 12 & 22 & 7 \\
\hline Fruits and vegetables & 0 & 115 & 89 & 26 & 7 & 3 \\
\hline Meat products & 139 & 120 & 256 & 3 & 27 & 21 \\
\hline Bakery and sweets & 0 & 150 & 139 & 11 & 25 & 19 \\
\hline Fish products & 0 & 160 & 124 & 36 & 37 & 27 \\
\hline Canned products & 5 & 70 & 64 & 11 & 18 & 17 \\
\hline Mushroom & 0 & 20 & 15 & 5 & 4 & 0 \\
\hline Frozen products & 0 & 75 & 68 & 7 & 7 & 4 \\
\hline Alcohol & 0 & 20 & 17 & 3 & 8 & 7 \\
\hline Soft drinks & 5 & 114 & 97 & 22 & 30 & 38 \\
\hline Spices and additions & 0 & 65 & 51 & 14 & 17 & 23 \\
\hline Snacks & 0 & 20 & 18 & 2 & - & - \\
\hline \hline Clothes & 0 & 19 & 10 & 9 & - & - \\
\hline Beauty and care & 0 & 16 & 3 & 13 & - & - \\
\hline Home products & 0 & 77 & 29 & 48 & 13 & 13 \\
\hline Other & 0 & 66 & 25 & 41 & 2 & 4 \\
\hline \hline TOTAL & 304 & 1197 & 1217 & 284 & 283 & 255 \\
\hline Note: Controlled presenyyyyy
\end{tabular}

Note: Controlled presents a number of products, the prices of which are controlled in category; Free presents a number of products, the prices of which are uncontrolled in category; Domestic presents a number of domestic goods in the category; Foreign presents a number of imported goods in the category; Search Index (Low) displays the number of brand names quires of which are below median; Search Index (High) displays the number of brand names quires of which is greater than the median; "-" means no observation.

The other extrinsic quality attribute is brand awareness presented by the Google search index. The greater amount of milk, soft drinks and spices and additions categories were produced by known brands.

Prices were collected in different years: 2005, 2007, 2008, 2009, 2010, 2011, 2012, 2013, 2014, 2015 and 2016. Therefore, the distribution of prices among categories with respect to years is presented in Table 3.

Table 3 - Price distribution among categories of goods.

\begin{tabular}{|c|c|}
\hline \multirow{2}{*}{ Categories } & UKRAINE \\
\cline { 2 - 2 } & LnPrice \\
\hline 1 & 2 \\
\hline Milk products & Base \\
\hline Groats and pastas & $-1.403^{* * *}$ \\
& $(0.229)$ \\
\hline \multirow{2}{*}{ Fruits and vegetables } & $1.182^{* *}$ \\
& $(0.531)$ \\
\hline Meat products & $0.299^{*}$ \\
& $(0.182)$ \\
\hline \multirow{2}{*}{ Bakery and sweets } & $0.293^{*}$ \\
& $(0.202)$ \\
\hline
\end{tabular}


table 3

\begin{tabular}{|c|c|}
\hline 1 & 2 \\
\hline Fish products & $\begin{array}{c}1.132^{* \star *} \\
(0.19)\end{array}$ \\
\hline Canned products & $\begin{array}{c}-0.546^{\star * *} \\
(0.207) \\
\end{array}$ \\
\hline Mushroom & $\begin{array}{l}-0.082 \\
(0.533) \\
\end{array}$ \\
\hline Frozen products & $\begin{array}{l}-0.049 \\
(0.331)\end{array}$ \\
\hline Alcohol & $\begin{array}{l}-0.191 \\
(0.354)\end{array}$ \\
\hline Soft drinks & $\begin{array}{c}-0.425^{\star * \star} \\
(0.18)\end{array}$ \\
\hline Spices and additions & $\begin{array}{l}-0.122 \\
(0.229) \\
\end{array}$ \\
\hline Snacks & - \\
\hline Clothes & - \\
\hline Beauty and care & - \\
\hline Home products & $\begin{array}{c}-0.873^{\star \star \star} \\
(0.255)\end{array}$ \\
\hline Other & $\begin{array}{c}0.213 \\
(0.371) \\
\end{array}$ \\
\hline $\mathrm{N}$ & 428 \\
\hline
\end{tabular}

Note: table present results from the following regression

$$
\text { lnPrice }_{i j}=\alpha+\beta \text { category }_{i}+\sum_{t=2}^{T} \gamma_{t} I\left(\text { Year }_{i j}=t\right)+u_{i j}
$$

Standard errors in parentheses

${ }^{*} p<0.1,{ }^{* *} p<0.05,{ }^{* * *} p<0.01$

Therefore, highly required products, according to consumption basket, have a significant price difference. Meat products are more expensive than milk products as well as fish products, bakery and sweets, fruits and vegetables and other categories. Eventually, there is price difference across product categories what makes necessary to control for category fixed effect.

Having described dataset, there are observable characteristics of a transition economy. However, in order to verify the stage of transition, it is necessary to provide more accurate analysis.

Results and discussions. With respect to the interest of our research, we are aimed to verify the ability of price to reflect quality in order to understand the dominance of market or the planned economy in transition consumption market of Ukraine.

For this purpose, intrinsic and extrinsic price effects are analyzed. Intrinsic quality attributes are presented by consumers' blind taste test results and producers' blind taste test results. Extrinsic cues are presented by country of origin, which is a dummy variable, and brand awareness. Moreover, the regression includes non-quality parameters, such as the type of the market according to the existence of price control policy, dummy variable, the frequency of usage, categorical variable, year fixed effect and category of product fixed effect.

Therefore, the results of the regression are presented in Table 4.

The results present intrinsic and extrinsic price effects in transition economy as well as the price difference between alternatives from price controlled and free markets. Therefore, there are the arguments for two main research hypotheses: needless of permanent price control policy (expedience of temporal 
PCP) and efficiency of permanent PCP.

Table 4. - Quality price effects

\begin{tabular}{|c|c|c|}
\hline \multicolumn{3}{|l|}{ UKRAINE } \\
\hline & No grouping & Group 1 \\
\hline & InPrice & InPrice \\
\hline \multicolumn{3}{|l|}{ Consumers' ratings } \\
\hline 1 - "worse" & Base & Base \\
\hline 2 - "bad" & $\begin{array}{c}0.247 \\
(0.169)\end{array}$ & \multirow{2}{*}{$\begin{array}{l}0.273^{*} \\
(0.145)\end{array}$} \\
\hline 3 - "good" & $\begin{array}{c}0.266^{*} \\
(0.158)\end{array}$ & \\
\hline 4 - "better" & $\begin{array}{l}0.018 \\
(0.155)\end{array}$ & \multirow{2}{*}{$\begin{array}{l}0.053 \\
(0.14)\end{array}$} \\
\hline 5 - "the best" & $\begin{array}{c}0.099 \\
(0.153)\end{array}$ & \\
\hline \multicolumn{3}{|l|}{ Professionals' ratings } \\
\hline 1 - "worse" & Base & Base \\
\hline 2 - "bad" & $\begin{array}{l}0.62^{* *} \\
(0.321)\end{array}$ & \multirow{2}{*}{$\begin{array}{l}0.715^{* *} \\
(0.296)\end{array}$} \\
\hline $3-$-good" & $\begin{array}{l}0.726^{*+t} \\
(0.298)\end{array}$ & \\
\hline 4 - "better" & $\begin{array}{l}0.763^{* * *} \\
(0.298)\end{array}$ & \multirow{2}{*}{$\begin{array}{l}0.65^{* *} \\
(0.297)\end{array}$} \\
\hline 5 - "the best" & $\begin{array}{l}0.265 \\
(0.319)\end{array}$ & \\
\hline Domestic & $\begin{array}{l}-0.6^{* * t} \\
(0.132)\end{array}$ & $\begin{array}{c}-0.604^{* * *} \\
(0.132)\end{array}$ \\
\hline GoogleTrend & $\begin{array}{l}-0.004^{*} \\
(0.002)\end{array}$ & $\begin{array}{l}-0.004^{*} \\
(0.002)\end{array}$ \\
\hline Controlled & $\begin{array}{l}0.42^{*+*} \\
(0.154)\end{array}$ & $\begin{array}{l}0.392^{* * *} \\
(0.154)\end{array}$ \\
\hline \multicolumn{3}{|l|}{ Frequency of usage } \\
\hline Low (low frequency of usage displays yearly and half a year consumption) & Base & Base \\
\hline $\begin{array}{l}\text { Medium (medium frequency of usage includes quarterly and monthly } \\
\text { consumption) }\end{array}$ & $\begin{array}{c}-1.286^{* * t} \\
(0.269)\end{array}$ & $\begin{array}{c}-1.281^{* * *} \\
(0.272)\end{array}$ \\
\hline High (high frequency of usage consists of weekly and daily usage) & $\begin{array}{c}-1.671^{* * *} \\
(0.3)\end{array}$ & $\begin{array}{c}-1.676^{\star \star \star} \\
(0.3)\end{array}$ \\
\hline Constant & $\begin{array}{c}1.781^{*} \\
\text { (1) }\end{array}$ & $\begin{array}{c}1.854^{*} \\
(1.002)\end{array}$ \\
\hline$N$ & 421 & 421 \\
\hline$R^{2}$ & 0.477 & 0.461 \\
\hline
\end{tabular}

Expedience of temporal PCP. Let start from the verifying the expedience of temporal PCP by providing analyze of the stage of transition of Ukrainian economy. In order to do it, we propose to establish ability of price to reflect quality.

Starting with intrinsic price effect, inside quality is presented by ratings of products made after blind taste test by consumers and experts. There are five possible evaluations, where 1 is worse and 5 is the 
best. As that it is categorical variable, we took "1-worse" as a base of comparison. Therefore, the product with consumers' evaluation "bad" or "good" has significantly greater price then the product with "worse" rating. However, professionals' evaluations have more powerful impact on price. In turn, the product with experts' rating "bad", "good" or "better" has significantly greater price then "worse" alternative. Significance of price effects between ratings are presented in Appendix B (Table B.2).

Based on the difference in price effects from various evaluations, it was decided to group evaluations into three categories: first one consists of products with "worse" rating ("bad" group), second one includes "bad" and "good" evaluation ("good" group) and third one has products with "better" and "the best" ratings ("the best" group). This task has few aims: 1) to simplify explanations of intrinsic cues and their price effects, 2) robustness check (more of varieties of grouping are presented in Appendix B.1) Therefore, the results from the model with grouping display that product with "good" evaluation has significantly greater price then the product with "bad" evaluation. In terms of professionals' evaluations, the product with rating from "good" group has significantly greater price, then "bad" alternative. However, based on regression results, "good" commodity has greater price even then "the best" good with respect to "bad" product as a base for comparison.

Eventually, there are significant difference between ratings and their price effects. However, in order to check significance of intrinsic price effect, we applied t-test. Therefore, the hypothesis that consumers' evaluations as well as professionals' evaluations does not have impact on price can be rejected with probability $98 \%$ (for the model with grouping). In turn, we cannot reject the hypothesis, that there is significant intrinsic price effect. Alternatively, the results show that in Ukrainian transition economy, price reflects intrinsic quality. Based on Lowengard and Cohen (2006), Oczkowski and Doucouliagos (2014), who stated that price conveys information about intrinsic quality, and our conclusion, that their findings are inherent to free market, the underlying outcome is that significant intrinsic price effect from consumption market is a feature of free market. Therefore, based on intrinsic price effect, Ukrainian economy adopts feature of free market, what moves it toward the last steps of transition.

However, there are extrinsic quality cues, which can present another direction of movement. Therefore, country of origin and brand awareness were chosen as proxies of extrinsic quality. From the regression results, both of these attributes have significant price effect, meaning that Ukrainian consumption market is characterized by significant extrinsic price effect. The robustness check is provided using t-test, where the hypothesis that country of origin as well as brand awareness have non-zero impact on price can be accepted with $100 \%$ probability. However, in order to understand the impact of this result on the stage of transition using literature suggestions, it is necessary to analyze country of origin price effect separately from brand awareness price effect.

Unfortunately, there is no strong evidence about brand awareness price effect from consumption market at free economy. However, Shwu-Ing and Li-Pang (2014) shows the positive brand awareness price effect at IT market, which is by its nature free market. The results of our regression present significantly negative brand awareness price effect, meaning, that the greater perception of the brand name, the lower is the price. The explanation might be based on the scale effect: known brands produce more, therefore, the prices can be decreased. Therefore, we might assume that significant brand awareness price effect is a feature of market economy. In contrast, supporting our assumption, Stride and Lee (2007) shows that brand awareness price effect for non-profit organizations, which are inherent to planned economy, is insignificant. Eventually, ability of price to reflect brand awareness serve as a signal of market economy, in turn, it moves Ukrainian economy toward free economy.

The second extrinsic attribute is country of origin. According to Thomas A.Wolf, in planned economy, because of the set of factors, among which is protection of domestic goods, price for imported products are higher than domestic. Unlike planned economy, according to Massow (1989), in free economy prices of domestic goods are close to the world market, therefore, there is no big difference between prices of 
imported and domestic commodities. Unfortunately, the results of regression display significant difference between domestic and imported goods. Moreover, domestic products are almost twice cheaper than imported alternatives. Therefore, such finding signals that Ukrainian economy in transition still have features of planned economy.

Therefore, extrinsic attributes, which are presented by country of origin and brand awareness, show opposite results. On the one hand, ability of price to reflect brand awareness is inherent to free economy, on the other hand, strong significantly high country of origin price effect is the echo from planned economy. In turn, there is no possibility to conclude about stage of transition based on extrinsic quality attributes and their ability to impact prices.

Eventually, we gathered all puzzles about intrinsic and extrinsic cues: price ability to reflect intrinsic quality and brand awareness suggests that Ukrainian consumption market adopts features of free economy, unlike country of origin price effect. Based on such outcome and the literature evidence, that intrinsic quality dominates extrinsic quality (Olson and Jacoby, 1971), the conclusion is that Ukrainian economy is on its last stages of transition. Alternatively, consumption market is able to distribute its resources efficiently without any government interactions. In turn, there is no more need in permanent price control policy. Moreover, our results show, that because there is still small echo from planned economy, providing temporal price control policy in case of emerging situations is advisable.

Efficiency of permanent PCP. The second research curiosity is the efficiency of provided permanent price control policy, which has been implemented till October, 2016. It based on the main idea of the policy: to make essential products affordable for poor people, e.g. to provide cheaper alternatives. In order to check policy efficiency, it is necessary to compare prices from free and controlled market.

Hedonic pricing regression make this task simple by providing the results for Controlled dummy. It is equal to one, if the product is in the list of essential goods, and zero otherwise. Therefore, the coefficient is significantly positive. It means, that price of the product from essential (price controlled market) is greater than the price of its alternative from the free market. This finding is the evidence of the negative overlooked effect of permanent price control policy, described by Christopher and Rachel Coyne (2015). They stated that the reason for it is little political pressure to reverse the controls and price control policy becomes disconnected in the minds of policymakers from the original aim of the policy. Alternatively, such price control policy is not efficient any more. Therefore, an inefficient price control policy is useless and requires revision. As result, our findings support the policy change what took place in October 2016.

Summary. This research is aimed to understand how correct was the Ukrainian government decision to stop permanent price control policy and introduce the temporary policy in October 2016. Because of the absence of the possibility to analyze the new policy, our strategy is based on two points: the first one is to understand needless of price control policy and the second one is to verify the efficiency of provided permanent PCP.

Price control policy is needed when the economy in early stages of its transition from planned to market, when on the one hand rapid process of liberalization increases prices, on the other hand, growing income inequality makes essential products not affordable for poor people (Alexeev and Leitz, 2001). The closer economy to a free market, the need in price control policy is lower (Morton, 2001). Therefore, in order to understand the needless of permanent price control policy, we proposed to understand the stage of transition of the Ukrainian economy. Based on the difference in abilities of price to reflect quality in the market and planned economies, we used it as a tool for covering research question. Moreover, the quality of the product was decomposed into intrinsic and extrinsic attributes, what allows to provide more accurate analysis. Therefore, based on the results from the hedonic regression, Ukrainian consumption market is characterized by significantly positive intrinsic price effect and significant brand awareness price effect. Literature evidence suggests that such price abilities are inherent to free markets. Only significant country of origin price effect displays features of the planned economy. Therefore, based on the findings and 
including the fact that intrinsic quality dominates intrinsic quality (Olson and Jacoby, 1971), the conclusion is that Ukrainian economy is on its last stages of transition to market economy. Therefore, consumer market is able to reallocate resources efficiently and satisfies the need of all consumers. Our finding supports the idea of Fiona Morton (2001), who claimed that "competition is a better tool than price controls for protecting consumers". As result, in the current stage of transition of the Ukrainian economy, there is no need in permanent price control policy.

In order to support the experience of the new temporal PCP, our results demonstrate that the last price control policy was inefficient. Using hedonic pricing regression, we showed, that the product from pricecontrolled market has greater prices than its alternative from the free market. Therefore, it underlines the negative overlooked effect from provided PCP.

Eventually, the results of this paper support government decision about cessation of the last policy. However, in order to continue movements of Ukrainian economy towards a market economy, the authority has to be very careful with providing temporal price control policy.

Acknowledgement. I thank Ukrainian Center for Expertise "TEST" and Yevgenija Kovalenko for providing data. I also thank Gerard Roland for his comments and suggestions. Moreover, I would like to thank Jan Hanousek for excellent supervision and patient guidance. All remaining errors are my own.

\section{APPENDIX A}

\section{List of products} Ukraine

Milk products: Kefir; Pasteurized milk 3.2\%; Fermented baked milk; Yogurt; Sour milk cheese 2-4\%; Cottage cheese desserts; Dutch cheese; Smoked cheese; Brynza; Butter; infant formula; Ice Cream Plombir; Cheese Radomerje 45\%; Cream cheese; Condensed milk

Meat products: Chicken sausages; Cooked and smoked bacon; Smoked salmon; Ukrainian salami; Pork ham; Vienna sausages; Sausages with cheese; Cooked sausage; Pelmeni; Smoked Sausage salami; Salceson; Smoked Pork Ribs; Fat pig; Chicken meat; Wieners; Liver pate; Meat Rolls; Mincemeat; Chicken gizzards; Stewed beef; Chicken thighs

Fish products: Tuna with butter; Crab sticks; Pink salmon salted; Dry gobies; Canned Saira; Red caviar; Hake; Yellow whale; Herring in oil with spicy vegetable additives; Preserves of herring; Carp; Artificial black caviar; Shrimps; Sardynella in oil; Trout; Pink salmon, canned; Alaska Pollack; Fish butter; Dry smelt; Assorted seafood (in oil)

Mushrooms: canned Luteus; Champignons

Frozen foods: Frozen chopped; Frozen pizza; Varenyky; Frozen vegetables; Doughnuts; Puff Pastry; Pancakes with cheese; Frozen cherry

Alcohol: Wine "Tamyanka"; Beer; Beer Mix; Champaign

Other drink: teas and coffees: Morse, fruit and berry; Carrot-apple juice; Black tea; Fit tea; Green tea; Coffee beans; Aerated water; Birch sap; Drinks juice; Nectar; Apple, orange, tomato juices; Water for children; Kvass from bread

Bakery and sweets: Raspberry jam; Milk Iris; Biscuit cakes; Marshmallow in chocolate; Prunes in chocolate; sugar Cookies; Biscuit cookies; Candies (Romashka, Diushes, Korivka, Ptashyne moloko, nuts in chocolate, waffles; Marmalade; Honey; Wafer rolls with chocolate filling; Napoleon cake; Cherry in chocolate; Kiev cake; Wafers "Artek"; Halva with peanuts; Milk chocolate; Yeast for baking; Turkish delight; oatmeal Cookies; Muffins with raisins

Groats and pastas: Pea grits; Croup; Potato starch; Thin noodles; Buckwheat flakes; Groats of Corn; Flour; Curly pasta (snails)

Canned vegetables and canned fast food: Buckwheat porridge with beef; Canned pepper; Green beans, canned; Tomatoes in own juice; Squash caviar; Canned corn; Cabbage Sauerkraut; Canned cucumbers

Fruits and vegetables: Cucumbers; Carrot; Tomatoes; Potato; Onion; Cabbage; Garlic; Beet; Lemon; Kiwi; Strawberry

Spices and other additions: A mixture of spices for chicken; Vinegar 9\%; Sauce "Satsebeli"; Ketchup Barbecue; Mix of spices for meat; Mayonnaise; Mustard

Snacks: Dried crust, salted; Cheaps; Salty popcorn

Clothes: Creepers; Men underwear; Women's tights 40 den; Children's Costumes

Beauty care: Lipstick; Suntan cream; Hair dye; Nail polish; Mascara; Face cream

Home stuff: Terry towels; Synthetic pillows; Sponges; Air freshener; Cleaning toilets; Teflon Pans; Water filters; Foil for baking; Soap; Ceramic Cup; Fen; A set of kitchen knives; Shoe polish

Others: Semi yarn; Christmas decorations; Christmas tree; Christmas candles; Protective face masks; Dry cat food;

Disposable tableware ; Sunglasses; Diapers; Heaters; School backpacks; Intraocular; Flavours for cars; Umbrella 


\section{APPENDIX B}

Table B.1 - Comparing models with different choice groups. Transition economy.

\begin{tabular}{|c|c|c|c|c|c|}
\hline \multicolumn{6}{|c|}{ UKRAINE } \\
\hline & No grouping & Group 1 & Group 2 & Group 3 & Group 4 \\
\hline & InPrice & InPrice & InPrice & InPrice & InPrice \\
\hline \multicolumn{6}{|l|}{ Consumers' choice } \\
\hline 1 - "worse" & Base & Base & Base & \multirow[b]{2}{*}{ Base } & \multirow{3}{*}{ Base } \\
\hline 2 - "bad" & $\begin{array}{c}0.247 \\
(0.169) \\
\end{array}$ & \multirow{2}{*}{$\begin{array}{l}0.273^{*} \\
(0.145)\end{array}$} & \multirow{3}{*}{$\begin{array}{c}0.167 \\
(0.137)\end{array}$} & & \\
\hline 3 - "good" & $\begin{array}{c}0.266^{\star} \\
(0.158) \\
\end{array}$ & & & \multirow{3}{*}{$\begin{array}{c}-0.018 \\
(0.102)\end{array}$} & \\
\hline 4 - "better" & $\begin{array}{c}0.018 \\
(0.155) \\
\end{array}$ & \multirow{2}{*}{$\begin{array}{l}0.053 \\
(0.14)\end{array}$} & & & \multirow{2}{*}{$\begin{array}{c}-0.711 \\
(0.685)\end{array}$} \\
\hline 5 - "the best" & $\begin{array}{c}0.099 \\
(0.153)\end{array}$ & & $\begin{array}{c}0.107 \\
(0.153)\end{array}$ & & \\
\hline \multicolumn{6}{|l|}{ Professionals' choice } \\
\hline 1 - "worse" & Base & Base & Base & \multirow[b]{2}{*}{ Base } & \multirow{3}{*}{ Base } \\
\hline 2 - "bad" & $\begin{array}{c}0.62^{* *} \\
(0.321)\end{array}$ & \multirow{2}{*}{$\begin{array}{l}0.715^{\star *} \\
(0.296)\end{array}$} & \multirow{3}{*}{$\begin{array}{c}0.724^{* * *} \\
(0.29)\end{array}$} & & \\
\hline 3 - "good" & $\begin{array}{l}0.726^{* \star \star} \\
(0.298)\end{array}$ & & & \multirow{3}{*}{$\begin{array}{c}0.167 \\
(0.147)\end{array}$} & \\
\hline 4 - "better" & $\begin{array}{l}0.763^{* * *} \\
(0.298)\end{array}$ & \multirow{2}{*}{$\begin{array}{c}0.65^{\star *} \\
(0.297)\end{array}$} & & & \\
\hline 5 - "the best" & $\begin{array}{c}0.265 \\
(0.319) \\
\end{array}$ & & $\begin{array}{c}0.23 \\
(0.32) \\
\end{array}$ & & - \\
\hline Domestic & $\begin{array}{c}-0.6^{* \star \star} \\
(0.132)\end{array}$ & $\begin{array}{c}-0.604^{* * *} \\
(0.132)\end{array}$ & $\begin{array}{c}-0.575^{\star * *} \\
(0.131)\end{array}$ & $\begin{array}{l}-0.625^{\text {***}} \\
(0.134)\end{array}$ & $\begin{array}{l}-0.487 \\
(0.306)\end{array}$ \\
\hline GoogleTrend & $\begin{array}{l}-0.004^{*} \\
(0.002)\end{array}$ & $\begin{array}{l}-0.004^{*} \\
(0.002)\end{array}$ & $\begin{array}{l}-0.004^{*} \\
(0.002)\end{array}$ & $\begin{array}{l}-0.004^{*} \\
(0.002)\end{array}$ & $\begin{array}{c}-0.004 \\
(0.004)\end{array}$ \\
\hline FrUsage_Low & Base & Base & Base & Base & Base \\
\hline FrUsage_Medium & $\begin{array}{c}-1.286^{* * *} \\
(0.269)\end{array}$ & $\begin{array}{c}-1.281^{* \star *} \\
(0.272)\end{array}$ & $\begin{array}{c}-1.263^{\star * *} \\
(0.269)\end{array}$ & $\begin{array}{c}-1.317^{* * *} \\
(0.274)\end{array}$ & $\begin{array}{c}-1.219^{* *} \\
(0.571)\end{array}$ \\
\hline FrUsage_High & $\begin{array}{c}-1.671^{* \star *} \\
(0.3)\end{array}$ & $\begin{array}{c}-1.676^{\star \star *} \\
(0.3)\end{array}$ & $\begin{array}{c}-1.633^{\star * *} \\
(0.297)\end{array}$ & $\begin{array}{c}-1.696^{* * *} \\
(0.303)\end{array}$ & $\begin{array}{l}-1.43^{* *} \\
(0.658)\end{array}$ \\
\hline Controlled & $\begin{array}{c}0.42^{* * *} \\
(0.154)\end{array}$ & $\begin{array}{c}0.392^{* * *} \\
(0.154)\end{array}$ & $\begin{array}{c}0.403^{* \star *} \\
(0.153)\end{array}$ & $\begin{array}{l}0.39^{* * *} \\
(0.156)\end{array}$ & $\begin{array}{c}0.156 \\
(0.3)\end{array}$ \\
\hline Constant & $\begin{array}{c}1.781^{*} \\
(1)\end{array}$ & $\begin{array}{c}1.854^{*} \\
(1.002)\end{array}$ & $\begin{array}{l}1.865^{*} \\
(0.991) \\
\end{array}$ & $\begin{array}{l}2.675^{\star *} \\
(0.957)\end{array}$ & $\begin{array}{l}3.753^{* \star *} \\
(1.132)\end{array}$ \\
\hline$N$ & 421 & 421 & 421 & 421 & 421 \\
\hline$R^{2}$ & 0.477 & 0.461 & 0.471 & 0.447 & 0.5 \\
\hline $\begin{array}{l}\text { Note: } \\
\text { Standart errors in } \\
{ }^{*} p<0.1,{ }^{* *} p<0.05 \text {, * }\end{array}$ & & & & & \\
\hline
\end{tabular}


Table B. 2 - Robustness check of significance of different ratings

\begin{tabular}{|c|c|c|c|c|}
\hline \multicolumn{5}{|l|}{ UKRAINE } \\
\hline & B1 & B2 & B3 & B4 \\
\hline & InPrice & InPrice & InPrice & InPrice \\
\hline \multicolumn{5}{|l|}{ Consumers' ratings } \\
\hline \multirow{2}{*}{1 - "worse" } & \multirow{2}{*}{ Base } & -0.247 & $-0.266^{*}$ & -0.018 \\
\hline & & $(0.168)$ & $(0.158)$ & $(0.155)$ \\
\hline \multirow{2}{*}{2 - "bad" } & 0.247 & \multirow{2}{*}{ Base } & -0.019 & 0.229 \\
\hline & $(0.169)$ & & $(0.154)$ & $(0.147)$ \\
\hline \multirow{2}{*}{3 - "good" } & $0.266^{*}$ & 0.019 & \multirow{2}{*}{ Base } & $0.248^{*}$ \\
\hline & $(0.158)$ & $(0.154)$ & & $(0.136)$ \\
\hline \multirow{2}{*}{4 - "better" } & 0.018 & -0.229 & $-0.248^{*}$ & \multirow{2}{*}{ Base } \\
\hline & $(0.155)$ & $(0.147)$ & $(0.136)$ & \\
\hline \multirow{2}{*}{5 - "the best" } & 0.099 & -0.148 & -0.167 & 0.081 \\
\hline & $(0.153)$ & $(0.147)$ & $(0.136)$ & $(0.13)$ \\
\hline \multicolumn{5}{|l|}{ Professionals' ratings } \\
\hline \multirow{2}{*}{1 - "worse" } & \multirow{2}{*}{ Base } & $-0.62^{* *}$ & $-0.726^{* \star *}$ & $-0.763^{\star * *}$ \\
\hline & & $(0.321)$ & $(0.298)$ & $(0.298)$ \\
\hline \multirow{2}{*}{2 - "bad" } & $0.62^{* *}$ & \multirow{2}{*}{ Base } & -0.106 & -0.142 \\
\hline & $(0.321)$ & & $(0.166)$ & $(0.169)$ \\
\hline \multirow{2}{*}{3 - "good" } & $0.726^{* \star *}$ & 0.106 & \multirow{2}{*}{ Base } & -0.037 \\
\hline & $(0.298)$ & $(0.166)$ & & $(0.106)$ \\
\hline \multirow{2}{*}{4 - "better" } & $0.763^{* \star \star}$ & 0.142 & 0.037 & \multirow{2}{*}{ Base } \\
\hline & $(0.298)$ & $(0.169)$ & $(0.107)$ & \\
\hline \multirow{2}{*}{5 - "the best" } & 0.265 & $-0.355^{*}$ & $-0.461^{* \star *}$ & $-0.497^{\star \star *}$ \\
\hline & $(0.319)$ & $(0.203)$ & $(0.152)$ & $(0.152)$ \\
\hline \multirow{2}{*}{ Domestic } & $-0.6^{* \star *}$ & $-0.6^{* * *}$ & $-0.6^{* \star *}$ & $-0.6^{* * *}$ \\
\hline & $(0.132)$ & $(0.132)$ & $(0.132)$ & $(0.132)$ \\
\hline \multirow{2}{*}{ GoogleTrend } & $-0.004^{*}$ & $-0.004^{*}$ & $-0.004^{*}$ & $-0.004^{*}$ \\
\hline & $(0.002)$ & $(0.002)$ & $(0.002)$ & $(0.002)$ \\
\hline \multicolumn{5}{|l|}{ Frequency of usage } \\
\hline Low & Base & Base & Base & Base \\
\hline \multirow{2}{*}{ Medium } & $-1.286^{\star \star \star}$ & $-1.286^{\star \star *}$ & $-1.286^{* *}$ & $-1.286^{\star \star *}$ \\
\hline & $(0.269)$ & $(0.269)$ & $(0.269)$ & $(0.269)$ \\
\hline \multirow{2}{*}{ High } & $-1.671^{\star \star \star}$ & $-1.671^{\star \star \star}$ & $-1.671^{* \star *}$ & $-1.671^{\star \star \star}$ \\
\hline & $(0.3)$ & $(0.3)$ & $(0.3)$ & $(0.3)$ \\
\hline Controlled & $0.42^{* * *}$ & $0.42^{* * *}$ & $0.42^{\star * *}$ & $0.42^{\star * *}$ \\
\hline & $(0.154)$ & $(0.154)$ & $(0.154)$ & $(0.154)$ \\
\hline Constant & $1.781^{*}$ & $1.781^{*}$ & $1.781^{*}$ & $1.781^{*}$ \\
\hline & (1) & (1) & (1) & (1) \\
\hline$N$ & 421 & 421 & 421 & 421 \\
\hline$R^{2}$ & 0.4768 & 0.4768 & 0.4768 & 0.4768 \\
\hline $\begin{array}{l}\text { Note: } \\
\text { Standart errors in paren } \\
{ }^{*} p<0.1,{ }^{* *} p<0.05,{ }^{* * *}<0 .\end{array}$ & & & & \\
\hline
\end{tabular}


APPENDIX C

Trends in essential goods. UKRAINE, 1991-2016

Panel B1 - List of goods prices of which are controlled by limited their value adds

\begin{tabular}{|c|c|c|c|c|c|c|c|c|c|}
\hline & 1999 & Changes & 2007 & $\begin{array}{c}\text { Change } \\
\text { s }\end{array}$ & 2008 & $\begin{array}{c}\text { Change } \\
\mathrm{s}\end{array}$ & 2011 & $\begin{array}{c}\text { Change } \\
\mathrm{s}\end{array}$ & 2016 \\
\hline 1 & Flour & + LNP & $X X X$ & - & $\mathrm{XXX}$ & - & $\mathrm{XXX}$ & - & $\mathrm{XXX}$ \\
\hline 2 & Bread & + LNP & $X X X$ & - & $X X X$ & - & $\mathrm{XXX}$ & - & $X X X$ \\
\hline 3 & Sugar & $\begin{array}{c}+D \\
(2008)\end{array}$ & $X X X$ & - & $X X X$ & - & $X X X$ & - & $X X X$ \\
\hline 4 & $\begin{array}{l}\text { Groats: } \\
\text { Buckwheat } \\
\text { Semolina }\end{array}$ & $\begin{array}{c}+D \\
(2011) \\
+\end{array}$ & $X X X$ & - & $X X X$ & - & $X X X$ & - & $X X X$ \\
\hline 5 & $\begin{array}{l}\text { Milk } \\
\text { (pasteurized } \\
\text { and sterilized) } \\
\text { with a fat } \\
\text { content of } 2.5 \% \\
\text { and } 3.2 \%\end{array}$ & $\begin{array}{c}+D \\
(2007)\end{array}$ & $X X X$ & - & $X X X$ & - & $X X X$ & - & $X X X$ \\
\hline 6 & $\begin{array}{l}\text { Saul cream with } \\
\text { a fat content } \\
\text { under } 20 \%\end{array}$ & $\begin{array}{c}+D \\
(2007)\end{array}$ & $X X X$ & - & $X X X$ & - & $X X X$ & - & $X X X$ \\
\hline 7 & Cheese & $\begin{array}{c}+D \\
(2007) \\
\end{array}$ & $X X X$ & - & $X X X$ & - & $X X X$ & - & $X X X$ \\
\hline 8 & $\begin{array}{l}\text { Butter with a fat } \\
\text { content under } \\
80 \%\end{array}$ & $\begin{array}{c}+D \\
(2007)\end{array}$ & $X X X$ & - & $X X X$ & - & $X X X$ & - & $X X X$ \\
\hline 9 & Sunflower oil & $\begin{array}{c}+D \\
(2008) \\
\end{array}$ & $X X X$ & - & $X X X$ & - & $X X X$ & - & $X X X$ \\
\hline 10 & Chicken meat & $\begin{array}{c}+D \\
(2007)\end{array}$ & $X X X$ & - & $X X X$ & - & $X X X$ & - & $X X X$ \\
\hline 11 & Eggs & $\begin{array}{c}+D \\
(2007)\end{array}$ & $X X X$ & - & $X X X$ & - & $X X X$ & - & $X X X$ \\
\hline 12 & $\begin{array}{l}\text { Cooked salam, } \\
\text { sausages }\end{array}$ & $\begin{array}{c}+\mathrm{D} \\
(2007)\end{array}$ & $X X X$ & - & $X X X$ & - & $X X X$ & - & $X X X$ \\
\hline & & + & $\begin{array}{l}\text { Meat } \\
\text { from } \\
\text { govern } \\
\text { ment } \\
\text { reserv } \\
\text { es } \\
\end{array}$ & - & $\begin{array}{l}\text { Meat } \\
\text { from } \\
\text { govern } \\
\text { ment } \\
\text { reserv } \\
\text { es } \\
\end{array}$ & - & $\begin{array}{l}\text { Meat } \\
\text { from } \\
\text { govern } \\
\text { ment } \\
\text { reserv } \\
\text { es } \\
\end{array}$ & - & $\begin{array}{l}\text { Meat } \\
\text { from } \\
\text { govern } \\
\text { ment } \\
\text { reserv } \\
\text { es } \\
\end{array}$ \\
\hline \multicolumn{10}{|c|}{$\begin{array}{l}\text { Note: "+" changes happened } \\
\text { LNP - good was transported to limited norm of profitability price control method } \\
\text { D - good was transported to declaration price control method } \\
\text { (Year) - the year, when product appears in the list of declaration price controlled goods } \\
\text { XXX - no product in the list any more }\end{array}$} \\
\hline
\end{tabular}


Panel B2 - List of goods prices of which are controlled by limited norms of profitability

\begin{tabular}{|c|c|c|c|c|c|c|c|}
\hline No & 2007 & Changes & 2008 & Changes & 2011 & Changes & 2016 \\
\hline 1 & $\begin{array}{l}\text { Products from } \\
\text { wheat flour } \\
\text { high, first and } \\
\text { second grade }\end{array}$ & 5 & $\begin{array}{l}\text { Products from } \\
\text { wheat flour } \\
\text { high, first and } \\
\text { second grade }\end{array}$ & 5 & $\begin{array}{l}\text { Products from } \\
\text { wheat flour } \\
\text { high, first and } \\
\text { second grade }\end{array}$ & 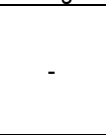 & $\begin{array}{l}\text { Products from } \\
\text { wheat flour } \\
\text { high, first and } \\
\text { second grade }\end{array}$ \\
\hline 2 & $\begin{array}{l}\text { Products made } \\
\text { from rye flour } \\
\text { bread } \\
\text { weighing more } \\
\text { than } 500 \text { grams } \\
\text { of wheat flour, } \\
\text { the first and } \\
\text { second grade } \\
\text { and their mixture } \\
\text { of rye flour and } \\
\text { flour mixes } \\
\text { wheat and rye } \\
\text { simple recipe } \\
\text { (flour, yeast, salt, } \\
\text { water) without } \\
\text { sugar, fat or } \\
\text { other fillers }\end{array}$ & - & $\begin{array}{l}\text { Products made } \\
\text { from rye flour } \\
\text { bread } \\
\text { weighing more } \\
\text { than } 500 \text { grams } \\
\text { of wheat flour, } \\
\text { the first and } \\
\text { second grade } \\
\text { and their mixture } \\
\text { of rye flour and } \\
\text { flour mixes } \\
\text { wheat and rye } \\
\text { simple recipe } \\
\text { (flour, yeast, salt, } \\
\text { water) without } \\
\text { sugar, fat or } \\
\text { other fillers }\end{array}$ & - & $\begin{array}{l}\text { Products made } \\
\text { from rye flour } \\
\text { bread } \\
\text { weighing more } \\
\text { than } 500 \text { grams } \\
\text { of wheat flour, } \\
\text { the first and } \\
\text { second grade } \\
\text { and their } \\
\text { mixture of rye } \\
\text { flour and flour } \\
\text { mixes } \\
\text { wheat and rye } \\
\text { simple recipe } \\
\text { (flour, yeast, } \\
\text { salt, water) } \\
\text { without sugar, } \\
\text { fat or other } \\
\text { fillers }\end{array}$ & - & $\begin{array}{l}\text { Products made } \\
\text { from rye flour } \\
\text { bread } \\
\text { weighing more } \\
\text { than } 500 \text { grams } \\
\text { of wheat flour, } \\
\text { the first and } \\
\text { second grade } \\
\text { and their } \\
\text { mixture of rye } \\
\text { flour and flour } \\
\text { mixes } \\
\text { wheat and rye } \\
\text { simple recipe } \\
\text { (flour, yeast, } \\
\text { salt, water) } \\
\text { without sugar, } \\
\text { fat or other fillers }\end{array}$ \\
\hline 3 & $\begin{array}{l}\text { Bread and } \\
\text { bakery products } \\
\text { for diabetics }\end{array}$ & - & $\begin{array}{l}\text { Bread and } \\
\text { bakery products } \\
\text { for diabetics }\end{array}$ & - & $\begin{array}{ll}\text { Bread } & \text { and } \\
\text { bakery } & \\
\text { products } & \text { for } \\
\text { diabetics } & \end{array}$ & - & $\begin{array}{l}\text { Bread and } \\
\text { bakery products } \\
\text { for diabetics }\end{array}$ \\
\hline
\end{tabular}

Panel B3 - List of goods prices of which are controlled by their declaration

\begin{tabular}{|c|c|c|c|c|c|c|c|}
\hline No & 2007 & Changes & 2008 & Changes & 2011 & Changes & 2016 \\
\hline 1 & $\begin{array}{l}\text { Wheat flour } \\
\text { high, first and } \\
\text { second grade }\end{array}$ & - & $\begin{array}{l}\text { Wheat flour } \\
\text { high, first and } \\
\text { second grade }\end{array}$ & - & $\begin{array}{l}\text { Wheat flour } \\
\text { high, first and } \\
\text { second grade }\end{array}$ & - & $\begin{array}{l}\text { Wheat flour } \\
\text { high, first and } \\
\text { second grade }\end{array}$ \\
\hline 2 & Rye flour & - & Rye flour & - & Rye flour & - & Rye flour \\
\hline 3 & Beef & - & Beef & - & Beef & - & Beef \\
\hline 4 & Pork & - & Pork & - & Pork & - & Pork \\
\hline 5 & Poultry & - & Poultry & - & Poultry & - & Poultry \\
\hline 6 & $\begin{array}{c}\text { Cooked } \\
\text { sausages }\end{array}$ & - & $\begin{array}{c}\text { Cooked } \\
\text { sausages }\end{array}$ & - & $\begin{array}{c}\text { Cooked } \\
\text { sausages }\end{array}$ & - & $\begin{array}{c}\text { Cooked } \\
\text { sausages }\end{array}$ \\
\hline 7 & $\begin{array}{c}\text { Milk } \\
\text { (pasteurized, } \\
\text { packed) }\end{array}$ & - & $\begin{array}{c}\text { Milk } \\
\text { (pasteurized, } \\
\text { packed) }\end{array}$ & - & $\begin{array}{c}\text { Milk } \\
\text { (pasteurized, } \\
\text { packed) }\end{array}$ & - & $\begin{array}{c}\text { Milk } \\
\text { (pasteurized, } \\
\text { packed) }\end{array}$ \\
\hline 8 & Cheese & - & Cheese & - & Cheese & - & Cheese \\
\hline 9 & Sour cream & - & Sour cream & - & Sour cream & - & Sour cream \\
\hline 10 & Butter & - & Butter & - & Butter & - & Butter \\
\hline 11 & Eggs & - & Eggs & - & Eggs & - & Eggs \\
\hline 12 & & + & Sugar & - & Sugar & - & Sugar \\
\hline 13 & & + & Sunflower oil & - & Sunflower oil & - & Sunflower oil \\
\hline 14 & & & & + & Buckwheat & - & Buckwheat \\
\hline
\end{tabular}

Alexeev, M. and Leitzel, J., (2001). Income distribution and price controls: Targeting a social safety net during economic transition, European Economic Review, Elsevier, vol. 45(9), pages 1647-1663.

Bao, X. H. H. and Wan T.K.A., (2007). "Improved Estimators of Hedonic Housing Price Models." JRER, 29 (3), $267-301$. 
Bilkey, W.J. \& Nes, E. (1982). Country-of-origin effects on product evaluations. Journal of International Business, 13(1), 89-99. Byerlee,D., Jayne, T.S. and Myers, R.J., (2007) Managing food price risks and instability in a liberalizing market environment: Overview and policy options. Food Policy 31 (4), 275-287

Coyne, J. C. \& L. R. (2015) The Economics of Price Control. Flaws and ceilings: Price Controls and The Damage They Cause. IEA, Institute of Economic Affairs, 2015

Dodds, W. B., Monroe, K. B., \& Grewal, D. (1991), "Effects of price, brand and store information on buyers' product evaluation". Journal of Marketing Research, 28(3), 307-319.

Fama, E. (1970). Efficient capital markets: A review of theory and empirical work, J. Finance 25. 383-417.

Farrell, J. (1980). Prices as Signals of Quality. PhD Thesis, Brasenose College, Oxford

Gabor, A. and Granger, C.W.J. (1966). Prices as an indicator of quality: report on inquiry. Economica, 33, 43-70

Garbarino, E. and Strahilevitz M. (2004). Gender differences in the perceived risk of buying online and the effects of receiving a site recommendation. Journal of Business Research, 57, 768-775.

Greenberg, Allan and Sy Collins (1966), "Paired Comparison Taste Test: Some Food for Thoughts", Journal of Marketing research, 3, pp. 76-80

Grossman, S.J. and Stiglitz, J.E. (1976). "Information and Competitive Price Systems". The American Economic Review, 66(2), 246-253

Hayek, Friedrich A. (1945). The Use of Knowledge in Society. American Economic Review. XXXV, No. 4. pp. 519-30

Jacoby, J., Olson, J.C. and Haddock, R.A. (1971), "Price, Brand Name and Product Characteristics as Determinants of Product Perceived Quality," Journal of Applied Psychology, 55 (6), 570-579.

Lancaster, K. (1966). "A New Approach to Consumer Theory". Journal of Political Economy, 74, 132-157.

Long, F., Paez, A. and Farber, S., (2007). "Spatial Effects in Hedonic Price Estimation: A Case Study in the City of Toronto". Working Paper Series, CSpA WP 020, McMaster University. Hamilton, ON: WP.

McConnell, J.D. (1968). The Price-Quality Relationship in an Experimental Setting. Journal of Consumer Research, 5, 334-346.

Morton, F.M.S. (2001) "The problems of price controls: History shows that these policies lead to shortages and stagnation; So

why do we want to control prescription drug prices?", Regulation, vol. 24, no. 1.

Neelankavil, J.P. and Rai, A. (2009) Basics of International Business. Published by Routledge Taylor and Francis Group, London and New York, p.77.

Nelson, P. (1970). Information and Consumer Behavior. Journal of Political Economy 78 (2): 311-329.

Oczkowski, E. and Doucouliagos, H., (2014). "Wine Price and Quality Ratings: A Meta-regression Analysis". American Journal of Agricultural Economics Advance Access, 1-19.

Olson, J.C. (1977), "Price as an Informational Cue: Effects on Product Evaluations," Consumer and industrial Buying Behavior, ed. Arch G. Woodside, Jagdish N. Seth and Peter D. Benett, New York, North Holland, 267-286.

Olson, J.C. and Jacoby, J. (1972), "Cue Utilization in the Quality Perception Process," Advances in Consumer Research, ed. M. Venkatesan, lowa City, IA: Association for Consumer Research, 167-179.

Rao, A.R. and Monroe K.B. (1989). The Effect of Price, Brand Name, and Store Name on Buyers' Perceptions of Product Quality: An Integrative Review, Journal of Marketing Research, 26(August), 351-7.

Rosen, S. (1974). "Hedonic Prices and Implicit Markets: Product Differentiation in Pure Competition". Journal of Political Economy 82(1), 34-55.

Shwu-Ing, W. \& Li-Pang, H. (2014). The Influence of Perceived Innovation and Brand Awareness on Purchase Intention of Innovation Product -- An Example of iPhone. International Journal Of Innovation \& Technology Management, 11(4), 1-22.

Smith, A. (1904). An Inquiry into the Nature and Causes of the Wealth of Nations. Edwin Cannan, ed. Library of Economics and Liberty. 30 April 2015.

Spence, M., (1974). Competitive and optimal responses to signals: An analysis of efficiency and distribution. Journal of Economic Theory, Elsevier, vol. 7(3), pages 296-332.

Stride, H. \& Lee, S. (2007) No Logo? No Way. Branding in the Non-Profit Sector., Journal of Marketing Management, 23:1-2, 107-122.

Wolf, T.A. (1988) Foreign trade in the centrally planned economy. Harwood Academic Publishers, Chur (1988)

У. Коломіець, CERGE-EI, Карловий університет, Інститут економіки Чеської академії наук (Прага, Чехія)

Політика державного регулювання цін в Україні

У жовтні 2016 р. Україна припинила політику тотального контролю над иінами на товари і послуги у сфері виробництва та реалізації продовольчих товарів, натомість був запроваджений тимчасовий режим, відповідно до якого в будь-який час влада може застосувати будь-які типи контролю над цінами на основні товари на період, що не перевищує 90 днів на рік. Термін «в будь-який час» означає ситуаиії, коли економіка та суспільство потребуватимуть втручання держави в процес ринкового ціноутворення, щоб контролювати ціни. Термін «будь-які типи контролю» означає, що влада може запроваджувати фіксовані (заморожені) чіни (найвищий рівень контролю), а також контроль декларацій виробників про ціноутворення (найнижчий рівень контролю). Оскільки така нова політика була започаткована у 2016 році, розуміння необхідності здійснення державного регулювання цін та оцінка ефективності реалізації проведеної

http://mmi.fem.sumdu.edu.ua/en 
рефрорми Уряду щодо дерегулювання цін стало основною метою даного дослідження. Обгрунтування необхідності проведення державного регулювання цін вимагає врахування транссормаційних процесів переходу економіки України з планової до ринкової. 3 цією метою у ході дослідження аналізувалась реакція ціни на відповідні трансформаційні процеси в економіці країни. Врахування внутрішніх та зовнішніх параметрів якості продукції дозволило автору забезпечити отримання більш точних результатів. Отримані результати засвідчили недоцільність постійної політики державного контролю над цінами на сучасному трансформаційному етапі переходу України до ринкової економіки. Результати використання гедонічної регресії показали ефективність впровадження цінової рефрорми 2016 року, оскільки контрольовані ціни товарів були вищі ніж сформовані альтернативні ціни вільного ринку.

Ключові слова: політика контролю цін (ПКЦ), ефективна та неефективна ПКЦ, перехідний ринок, ринок основних товарів, тимчасовий та постійний ПКЦ 